Article

\title{
Trade Openness and Carbon Emissions: Evidence from Belt and Road Countries
}

\author{
Huaping Sun $1,2, * \mathbb{C}$, Samuel Attuquaye Clottey ${ }^{2, *} \mathbb{C}$, Yong Geng ${ }^{1,2}$, Kai Fang ${ }^{3}$ and \\ Joshua Clifford Kofi Amissah ${ }^{2}$ \\ 1 School of Environmental Science and Engineering, Shanghai Jiao Tong University, Shanghai 200240, China; \\ ygeng@sjtu.edu.cn \\ 2 Division of Low-carbon Economy and Environmental Regulation, Institute of Industrial Economics, \\ Jiangsu University, Zhenjiang 212013, China; joshuaamissah505@gmail.com \\ 3 School of Public Affairs, Zhejiang University, Hangzhou 310058, China; fangk@zju.edu.cn \\ * Correspondence: shp@ujs.edu.cn (H.S.); attuquye1882@gmail.com (S.A.C.); \\ Tel.: +86-511-88792188 (H.S. \& S.A.C.)
}

Received: 22 February 2019; Accepted: 3 May 2019; Published: 10 May 2019

\begin{abstract}
The search for a green and low-carbon economy has been a guide to current energy and environmental research. Using current panel cointegration approaches, our study examines the interaction between trade and an environmental pollution proxy of carbon dioxide $\left(\mathrm{CO}_{2}\right)$ emissions by integrating economic growth and energy usage as major potential determining factors in this relationship for 49 high-emission countries in Belt and Road regions over the period of 1991-2014. For a robust analysis, we further grouped these countries into income panels (high, middle, low) and various regions (East Asia, Southeast Asia, Central Asia, South Asia, the Middle East/Africa, and Europe). The results of the panel cointegration tests revealed that the four variables were stationary in the long run. Similarly, our panel results indicated that trade openness had both positive and negative impacts on environmental pollution, but the effect varied in these different groups of nations. The results of the vector error correction model (VECM) causality also showed a long-run causal effect between trade, economic growth, energy consumption, and environmental pollution in the Belt and Road, Europe, high-income, middle-income, and low-income panels. The environmental Kuznets curve $(E K C)$ results further indicated the existence of an inverted U-form relationship between trade and carbon emissions. Finally, certain policy implications are discussed.
\end{abstract}

Keywords: trade openness; carbon emissions; economic growth; Belt and Road; EKC

\section{Introduction}

Economic study of the trade openness and $\mathrm{CO}_{2}$ emissions relationship has undoubtedly become a major concern for economists, policymakers, and the general public. Since the emergence of the "General Agreement on Tariffs and Trade" (GATT), trade between countries has increased significantly, enhancing trade liberalization. Similarly, the reconstitution of the GATT to the World Trade Organization (WTO) has greatly encouraged global trade. The most recent strategy is the establishment of the "Trade Facilitation Agreement" (TFA) [1], which is estimated to stimulate global trade by up to USD 1 trillion annually, with the greatest paybacks occurring for developing countries. However, the main concern of the TFA is its long-run global externality effects. The reciprocity of international trade was previously well proven in trade economics by Adam Smith and David Ricardo in their absolute advantage theory and comparative advantage theory, respectively, revealing that developing nations with receptive economic policies enjoy the mutual trade returns. In 2001, China officially entered the WTO, and since then it has been heavily involved in international competition and global 
cooperation. A more recent study identified trade openness as the primary driving force behind China's economic development. For example, a report from the United Nations Statistics Division [2] provided statistics on the volume of Chinese merchandise exports, which was estimated to reach USD 2263.3 billion in 2017, representing $13.8 \%$ of exports worldwide. Additionally, the value of imports increased to USD 1843.7 billion during that same period, although its imports system was markedly different from that of exports. This transformation was accompanied by a wider range of $\mathrm{CO}_{2}$ emissions from exports to several nations at the expense of Chinese energy usage and a safe environment, with figures of petroleum and iron raw materials recording about $10.9 \%$ of Chinese imports [2]. Within the scope of industrialization, pollution from global trade constituted a substantial share of world $\mathrm{CO}_{2}$ emissions in 2008. Moreover, carbon emissions embodied in global value chains are increasing more rapidly than some economic indicators, for example, population or real income [3]. An increasing number of empirical works have been carried out to determine the trade and $\mathrm{CO}_{2}$ emissions relationship [4-7]. However, the results from this research have been variable (finding either positive or negative relationships), and a specific consensus has not been reached. This has generated much concern for current studies on the subject, prompting researchers to include economic growth, energy consumption, urbanization, and foreign direct investment (FDI) in the investigation of the relationship between trade openness and environmental quality [8-10]. In economic theory, we know that increasing trade enhances growth. Similarly, increasing growth adversely affects the environment by releasing emissions into the atmosphere. We then expect the countries affected to implement more environmentally friendly production techniques to enhance the quality of the environment.

In September 2013, at Nazarbayev University, the president of China revealed the biggest infrastructure plan ever announced as part of his state visit to Kazakhstan (now known as the Belt and Road Initiative (BRI), with the aim of improving connections and support between countries in the Eurasian region in order to encourage trade [11-13]. The BRI reflects the trends of economic globalization and is aimed at spreading China's development opportunities throughout the Eurasian region to achieve common prosperity. When fully implemented, the BRI is expected to change the locality, supply, and trade structures of China. China has been instrumental in increasing global emissions to date, overtaking countries such as the USA, India, and Japan. The Energy Information Administration has reported that China's $\mathrm{CO}_{2}$ emissions dramatically increased by $170 \%$ between 2000 and 2009 and are still rising [14]. This rapid rise in $\mathrm{CO}_{2}$ emissions can be attributed to its very high emission intensity and strong reliance on coal for production [15]. In 2009, around 82\% of China's electricity production was generated using conventional energy, primarily coal [14]. China's growing urban development means that the construction industry, accompanied by electricity production, accounts for a substantial share of emissions from households [16]. Although studies have recently been conducted on the trade-emissions nexus [8,17-21], very few have investigated this relationship in Belt and Road countries as a whole [20-22]. These countries have been recognized over the past years as major drivers of world economic growth within emerging markets, and current research has forecasted them to be among the most dominant economies in the coming years. Additionally, previous research has failed to consider the presence of the environmental Kuznets curve (EKC) framework when investigating the effects of BRI projects on trade, energy consumption, and economic growth and their adverse impact on global environmental quality. The theory behind the EKC started in the early 1990s with Grossman et al. [23] during research on the possible effects of the North American Free Trade Agreement (NAFTA) and an empirical study by Shafik et al. [24] for the 1992 World Development Report. However, the EKC theory was made famous in the 1992 World Development Report of the International Bank for Reconstruction and Development (IBRD) by retaining the opinion that increased economic activity undoubtedly harms the environment; due to lack of innovations, creativity and economic investment. Many scholars have explained this situation more aggressively, with Beckerman [25] arguing that "even though growth in the economy normally contributes to deterioration of the environment at the initial stages of development, in most countries, the most possible way to achieve a safe surrounding is through development". The EKC theory has not once 
been proven to be applicable to all emissions or ecological factors, and current research has disputed the concept of the EKC at large. Increasing production costs due to strict environmental standards has been a menace to global competition, according to manufacturers. The fundamental theory is that pollution-intensive firms in countries with friendly environmental standards enjoy more economic benefits, more than the similar firms located in countries with rigorous environmental laws. However, issues with regard to the potential negative environmental effects of open trade have been widely discussed, with the fear that a highly incorporated global economy (for instance, NAFTA, the European Union, and the WTO) will accelerate the depletion of resources, increase global emissions, and promote dumping in low-income economies. The level of a country's real GDP is a major factor in determining environmental regulations. However, inequalities in the cost of complying with environmental standards are the main reason for trading in dirty commodities.

Against this background and the 2030 agenda for sustainable development on climate change by the World Bank, this paper examines the immediate and long-term economic effects of real income, international trade, and energy consumption on environmental quality using panels from countries within Belt and Road regions over the period of 1991-2014. With this, we hope to add to existing studies by investigating the performance of trade and its long-term impacts on the environment. Our work contributes in multiple ways to current research. First, we used panel data from Belt and Road regions to empirically investigate the relationship between trade and environmental quality using the Granger causality approach of Engle et al. [26]. Again, for robust analysis, we used the most suitable and current long-term panel modus operandi, together with the panel cointegration estimate recommended by Pedroni [27]. We also discuss the complexity of the trade openness and $\mathrm{CO}_{2}$ emissions relationship, pointing out that more trade does not always mean more emissions, and more emission levels do not necessarily involve more trade.

The manuscript adopts the following structure: Section 2 provides brief assessments on the related literature. Section 3 is the data, methodology, and empirical evidence used. Section 4 reveals and explains the empirical results. Section 5 concludes the study and provides several policy implications.

\section{Literature Review}

\subsection{The Pollution Haven Hypothesis}

In most cases, the pollution haven hypothesis ( $\mathrm{PHH}$ ) by Copeland et al. [28] explains the influence of trade on the environment. Strict environmental regulations in a country force companies to relocate to economies with friendly environmental laws. We can therefore classify the PHH as low environmental regulations that provide countries with comparative advantages that distort international trade patterns. Since many developing countries have an edge in the production of pollution-intensive commodities, their supply may be shifted to developing nations due to trade liberalization. The total effect of international trade on pollution is therefore obscure. The impacts of free trade on the environment are fully explained by composition, scale, and technology effects $[4,29,30]$. The scale effect shows that economic growth, mainly due to trade, worsens the environment due to the expansion of energy demand resulting from increased economic activity. However, as countries embrace free trade, higher income levels can lead to environmental improvements at the peak of economic prosperity. The composition effect explains that countries should change their production process based on their comparative advantage. When demand for traded goods manufactured by contaminating methods increases, countries in turn produce polluted goods ceteris paribus. This results in the movement of the polluting sector from industrialized nations to underdeveloped economies [30]. Thus, reaffirming Grossman et al. [31], the net composition effect is that environmental improvements are fueled by higher income levels, but this result could be biased due to the comparative size of the environmental regulatory effect and the capital-labor effect in those industrial economies [32]. Finally, the technical effect explains the environmental impacts of transferred knowledge and innovative production methods as income and trade expand. Through trade liberalization, the transfer of environmentally 
friendly technologies and energy-efficient production techniques between countries can lead to lower greenhouse gas (GHG) emissions, specifically $\mathrm{CO}_{2}$. Therefore, classifying a country as a pollution haven depends on the above-mentioned features.

\subsection{Trade Openness and Carbon Emissions}

A number of works have developed empirical and theory-based models for analyzing the impact of trade liberalization on the environment [5]. The impact of international trade on environmental sustainability is an essential component in the formulation of trade policies. Using the simultaneous equation model [33], the impact of $\mathrm{CO}_{2}$ emissions on trade openness and other indicators for 14 Middle Eastern and North American (MENA) nations was studied between 1990 and 2011. The outcome showed that the effect of open trade on pollution in these economies was inverse and statistically unimportant. Utilizing the fully modified ordinary least squares (FMOLS) technique, Shahbaz et al. [6] analyzed 105 countries, obtaining data for the period 1980-2014 and grouping them into samples of worldwide, high- (developed), middle- (developing), and low-income (underdeveloped) groups. The research showed an inverted U-form nexus between trade and environmental quality for all groups. Similarly, Shahbaz et al. [34] found that trade openness improves pollution, since free trade fosters a greater level of research and development associated with foreign direct investment (FDI). Sohag et al. [35] investigated the impacts of real income, trade, population increases, and energy consumption on $\mathrm{CO}_{2}$ emissions using data from 82 developing nations between 1980 and 2012 using various mean group (MG) approaches (cross-correlated and augmented). The results showed that a percentage increase in trade (holding all of the other explanatory variables constant) reduces $\mathrm{CO}_{2}$ pollution by $0.3 \%$. Meanwhile, the results were inconclusive for low-income, middle-income, and full sample countries. Managi et al. [36] used the instrumental variables modus operandi to estimate the overall effect of trade on environmental quality. The results showed that global trade increases emissions in non-advanced economies, with a contradictory reaction in advanced economies: this increase was attributed to the scale and composition effects of trade. By using industrial data from various Chinese provinces from 1997-2007, Jayanthakumaran et al. [37] examined the relationship between real income, global trade, $\mathrm{CO}_{2}$ emissions, and sulfur dioxide $\left(\mathrm{SO}_{2}\right)$ particulates, confirming that international trade minimizes greenhouse gas emissions by increasing income and promoting an overall increase in consumer expenditure on environmentally friendly goods. Unresolved empirical research could have possibly occurred due to omitted variables, since a number of pollutants react contrarily to various trade factors and since the impact of trade on the environment is nation-precise, which may depend on the income level and political institutions of countries. In addition, few studies on the subject have involved Belt and Road countries as a whole, thereby creating the zeal for this research.

\subsection{Real Income, Energy Consumption, and $\mathrm{CO}_{2}$ Emissions}

A school of thought has argued that the above economic indicators are interrelated and need to be studied together [38]. For instance, an EKC study confirmed that rising incomes do not always reduce $\mathrm{CO}_{2}$ emissions, arguing that environmental pollution typically increases as income increases (Salahuddin et al. [39] and Farhani et al. [40]). In addition, since energy usage has a significant effect on the quality of the environment, it is feasible to examine these two components using a joint mechanism to minimize inaccuracy. Likewise, because the three elements are related, their relationships may be tested simultaneously by a joint mechanism: specifically, in accordance with studies conducted by Keppler et al. [41] in the UK; in Brazil, Russia, India, China, and South Africa (BRICS) by Pao et al. [42]; in India by Ghosh [43]; and in China by Zhang et al. [44]. However, their results were different due to the various approaches, data, and nations used in their research. Over the past two decades, the real income and environmental pollution relationship has been well examined in the literature: This research has mostly been linked to the EKC framework. Much of the previous research on this relationship has supported the inverted U-shaped relationship, often described as the EKC theory. Since Grossman and Krueger [23,45], this relationship has been further investigated. Saboori et al. [46], 
Ozturk et al. [47] and Fodha et al. [48] examined the EKC framework in their research, but their analysis showed a scope of inconsistent outcomes. For instance, a linear relationship, $\mathrm{N}$-shaped relationship, and U-shaped relationship have appeared in the literature. An omitted variable bias issue was identified as the key limitation in the previous studies. Therefore, some current research has integrated other variables that influence environmental pollution, such as urbanization, trade openness, financial development, and energy consumption, into studies. This multivariate analysis, however, has also generated various outcomes for the EKC theory [33,47]. Using a bootstrap panel unit root test and cointegration method, Arouri et al. [38] investigated the nexus between real income, energy usage, and $\mathrm{CO}_{2}$ emissions for 12 MENA countries between 1981 and 2005. Their results showed increasing long-run relationships between energy usage, real income, and $\mathrm{CO}_{2}$ emissions. This also revealed that economic growth had a quadratic relationship with environmental pollution in the 12 countries. They further emphasized that while the long-term coefficient estimates of real GDP met the EKC framework in the selected nations; their threshold points were different, thus failing to fully explain the EKC hypothesis. Acheampong [49] employed panel vector autoregression (PVAR) together with a system generalized method of moment (GMM) to investigate the changing causality between $\mathrm{CO}_{2}$ emissions, energy consumption, and economic growth in 116 nations between 1990 and 2014. Their outcomes established that real income does not influence global and territorial energy usage. Again, apart from worldwide and the Caribbean/Latin America, real income had no causal effect on environmental pollution. In addition, energy usage increased real income in Sub-Saharan Africa and inversely affected real income in the Caribbean/Latin America. Finally, apart from MENA nations, environmental pollution did not affect the use of energy in the global sample, with countries in Sub-Saharan Africa showing evidence of the EKC framework. Gorus et al. [50] also examined the causality between real income, energy usage, and pollution using various Granger causality approaches in eight MENA oil-endowed economies between 1975 and 2014. The examination of the panel frequency domain showed a cause-and-effect relationship between all the underlying variables in different frequencies relative to the causal relationships of the time domain. Previous studies have failed to include both regional and income levels in their analysis, making it difficult to explain the extent to which energy consumption and real income affect environmental pollution in this group of nations.

\section{Model and Empirical Analysis}

\subsection{Methodology and Data Collection}

This section defines the framework and data used for the empirical analysis of the trade and environmental relationship. We compiled data on $\mathrm{CO}_{2}$ emissions, real income, trade, and energy usage from the World Bank online data bank (2017) for 49 high-emission countries in Belt and Road regions (Table 1). Our data were yearly, ranging from 1991 to 2014. We further grouped the data into region and income groups. Many elements were employed to measure pollution in the literature, including $\mathrm{SO}_{2}$, nitrogen oxide (NO), and $\mathrm{CO}_{2}$, etc. However, we used $\mathrm{CO}_{2}$ in our analysis because of its global effects. For instance, a report from the Environmental Protection Agency (EPA) showed the health problems associated with $\mathrm{CO}_{2}$ emissions in the atmosphere [51].

Table 1. Definition of variables.

\begin{tabular}{ccc}
\hline Variable & Definition & Units of Measurement \\
\hline $\mathrm{CO}_{2}$ & Carbon emissions per metric ton & Metric ton \\
$Y$ & GDP per capita & Current USD \\
$\mathrm{TR}$ & Import + export & Current USD \\
$E C$ & Energy consumption & $\mathrm{kg}$ of oil equivalent per capita \\
\hline
\end{tabular}


Our work selected and used available data for the empirical analysis. We presupposed that the main forces of economic development were trade and energy usage, so we defined environmental pollution as an end product of energy consumption in relation to trade and economic growth.

Hence, we defined our models:

$$
\mathrm{CO}_{2 i t}=f\left(Y_{i t}, T R_{i t}, E C_{i t}\right)
$$

We altered all selected variables into natural logarithms in order to minimize the heteroscedasticity problem and get the growth level of the parameters by their log differences to compute Equation (2), using it to examine the relationship between the dependent and independent variables, following the works of [52-55]:

$$
\ln C O_{2 i t}=\alpha_{0}+\alpha_{1} \ln Y_{i t}+\alpha_{2} \ln T R_{i t}+\alpha_{3} \ln E C_{i t}+\varepsilon_{i t},
$$

where $\ln \mathrm{CO}_{2 i t}$ indicates the natural $\log$ of $\mathrm{CO}_{2}$ emissions; $\ln Y_{i t}$ denotes the natural log of real income as a proxy for economic growth; $\ln T R_{i t}$ shows the natural log of trade openness; and $\ln E C_{i t}$ shows the natural $\log$ of energy consumption. The normal or stochastic error term $\varepsilon_{i t}$ is assumed to be normally distributed. The coefficients $\alpha_{1}, \alpha_{2}$ and $\alpha_{3}$ indicate the elasticity of environmental pollution with respect to real income, trade, and energy consumption, respectively, and $\alpha_{0}$ is the constant parameter. If $\alpha_{1}<0$, this shows that economic growth $\left(Y_{i t}\right)$ is substitute for environmental pollution $\left(\mathrm{CO}_{2 i t}\right)$, and otherwise the two are complements, that is, when $\alpha_{1}>0$. This means that increasing real income will consequently increase energy consumption and thereafter cause pollution in the atmosphere to rise. If $\alpha_{2}<0$, this means that global trade will deteriorate energy concentration through the technical effect by refining the environment, and it will inversely affect economic growth by increasing energy demand, leading to a potential rise in $\mathrm{CO}_{2}$ emissions, thus reducing environmental quality when $\alpha_{2}>0$. If $\alpha_{3}<0$, this implies that the effect of energy usage on environmental pollution is negative, or else positive.

As for the anticipated outcomes, we expected $\alpha_{1}$ to be positive, implying that increasing real income will increase environmental pollution. For $\alpha_{2}$, we expect mixed signs (positive or negative), as in the economic literature. According to Kohler [56], this varies depending on the degree of economic development. We expected a negative sign for developed countries, since developed countries at a certain point stop manufacturing emission-intensive commodities and import them from nations with lenient environmental regulations. With regard to emerging economies, we expected a positive sign, because pollution-intensive sectors appear to emit a larger percentage of pollutants. We expected the sign of $\alpha_{3}$ to be positive, since higher energy consumption is expected to increase environmental pollution.

Finally, following the theory behind the EKC analysis, we examined the reality of an inverted $\mathrm{U}$-shape relationship between trade openness and $\mathrm{CO}_{2}$ emissions. We introduced the square of trade into Equation (2) to compute Equation (3), using this equation to confirm the rationality of the EKC hypothesis in our model. Following the work of Shahbaz et al. [6], we defined our EKC model as below:

$$
\ln C O_{2 i t}=\alpha_{0}+\alpha_{1} \ln Y_{i t}+\alpha_{2} \ln T R_{i t}+\alpha_{3} \ln \left(T R_{i t}^{2}\right)+\alpha_{4} \ln E C_{i t}+\varepsilon_{i t},
$$

where $\alpha_{0}$ in the model is the interception parameter, which differs between country $i$ and year $t$. The basic theory is that [57] while pollution levels per metric ton may vary across nations at any given level of trade, the coefficient of trade openness is constant for all nations at a particular level of trade. The threshold point of trade openness, where pollution is maximized, is determined by

$$
\pi=\exp \left(-\alpha_{2} / 2 \alpha_{3}\right)
$$




\subsection{Data Tests and Analysis}

\subsubsection{Cross-Sectional Dependence Test}

An economic analysis with panel data had several merits over cross-sectional and time series data. Using panel data in particular [43] enabled further observations by combining time series data between nations and further generated greater exponents for estimating the Granger causality test. In addition, when using panel data, we could control exogenous sources of individual heterogeneity that varied over specific periods. Since trade openness generally involves several nations, it became very important to take into account the influence of cross-sectional dependence on the selected dataset. We therefore began our analysis with a cross-sectional dependence test. The existence of cross-sectional dependency in a cross-country panel analysis occurs due to unnoticed common shocks or model misspecifications that are part of the error terms. Cross-sectional dependency within panels may be described as weak or strong, but negligence in determining the presence of cross-sectional dependency between selected variables can lead to bias estimations as well as inconsistent standard errors of the estimated parameters [58]. Therefore, by using the one parametric test proposed by Pesaran et al. [58,59], and Breusch et al. [60], we examined the existence of cross-sectional dependency within our selected panels. The cross-sectional dependency lagrange multiplier $\left(C D_{L M}\right)$ [58] test sums the squares of the correlation coefficient between cross-sectional residuals. This technique is used when $T>N$ or $N>T$, where $N$ is (the cross-sectional dimension) and $T$ is (the time dimension of the panel) and is asymptotically standard and normally distributed. The null and alternative hypotheses were consistent with the $C D_{L M 1}$ test used by Breusch et al. [60]. This test is calculated using the following formula:

$$
C D_{L M}=\sqrt{\frac{2 T}{N(N-1)}}\left(\sum_{i=1}^{N-1} \sum_{j=i+1}^{N} \hat{\rho}_{i j}\right),
$$

where $\hat{\rho}_{i j}$ represents the sample outcome of the pairwise correlation of the residual, which is defined as:

$$
\rho_{i j}=\rho_{j i}=\frac{\sum_{t=1}^{T} \varepsilon_{i t} \varepsilon_{j t}}{\left(\sum_{t=1}^{T} \varepsilon_{i t}^{2}\right)^{1 / 2}\left(\sum_{t=1}^{T} \varepsilon_{j t}^{2}\right)^{1 / 2}} .
$$

The null and alternative hypotheses to be verified were $\rho_{i j}=\rho_{j i}=\operatorname{corr}\left(\varepsilon_{i t}, \varepsilon_{t j}\right)=0$ for $i \neq j$ and $\left(\rho_{i j}=\rho_{j i} \neq 0\right)$ for specific $i \neq j$, respectively. The $C D_{\text {LM1adj }}$ test of Pesaran et al. [59] is an extended form of the $C D_{L M 1}$ estimation formulated by Breusch et al. [60] and is expressed below:

$$
C D_{M L 1 a d j}=\frac{1}{C D_{L M 1}}\left[\frac{(T-k) \rho_{i j}^{2} \mu T}{\sqrt{v_{i j}^{2}}}\right],
$$

where $N \sim(0,1)$ and $C D_{L M 1}$ is computed as

$$
C D_{L M 1}=T \sum_{i=1}^{N-1} \sum_{j=i-1}^{N} \hat{\rho}_{i j}^{2}
$$

This test also squares and adds the correlation coefficients between cross-sectional residuals after the ordinary least square (OLS) estimation and is used when $N$ is constant and $T$ approaches infinity and has $N(N-1) / 2$ degrees of freedom (Table 2). Below are the null and alternative hypotheses for this test: $H_{0}$ (there is no relationship between cross-sections) and $H_{1}$ (there is a relationship between cross-sections). 
Table 2. Dependency test result.

\begin{tabular}{|c|c|c|c|c|}
\hline Countries & Variable & Breusch-Pagan LM & Pesaran LM & Pesaran CD \\
\hline \multirow{4}{*}{ Belt and Road } & $\ln \mathrm{CO}_{2 i t}$ & $12,926.99(0.0000)$ * & $242.3014(0.0000) *$ & $22.43205(0.0000)$ * \\
\hline & $\ln Y_{i t}$ & $24,017.5(0.0000)$ * & $470.9839(0.0000)$ * & $154.6236(0.0000)$ * \\
\hline & $\ln T R_{i t}$ & $24,985.2(0.0000)$ * & $490.9374(0.0000)$ * & $157.8545(0.0000)$ * \\
\hline & $\ln E C_{i t}$ & $7994.459(0.0000)$ * & $140.5943(0.0000)$ * & $25.11911(0.0000)$ * \\
\hline \multirow{4}{*}{ High-Income } & $\ln C \mathrm{O}_{2 i t}$ & $1185.95(0.0000)^{*}$ & $63.66259(0.0000)$ * & $0.51182(0.6088)$ \\
\hline & $\ln Y_{i t}$ & $2907.51(0.0000)$ * & $168.0475(0.0000)$ * & $53.86982(0.0000)$ * \\
\hline & $\ln T R_{i t}$ & $2988.747(0.0000)$ * & $172.9732(0.0000)$ * & $54.61348(0.0000)$ * \\
\hline & $\ln E C_{i t}$ & $603.4995(0.0000)$ * & $28.34632(0.0000)$ * & $4.733538(0.0000)$ * \\
\hline \multirow{4}{*}{ Middle-Income } & $\ln C \mathrm{O}_{2 i t}$ & $4183.259(0.0000)$ * & $151.3334(0.0000)$ * & $14.87076(0.0000)$ * \\
\hline & $\ln Y_{i t}$ & $6642.774(0.0000)$ * & $247.8035(0.0000)$ * & $81.33934(0.0000)$ * \\
\hline & $\ln T R_{i t}$ & $6853.511(0.0000)$ * & $256.0693(0.0000)$ * & $82.66953(0.0000)$ * \\
\hline & $\ln E C_{i t}$ & $2780.408(0.0000)$ * & $96.30902(0.0000)$ * & $17.34194(0.0000)$ * \\
\hline \multirow{4}{*}{ Low-Income } & $\ln C \mathrm{O}_{2 i t}$ & $143.0766(0.0000)$ * & $23.38349(0.0000)$ * & $7.67568(0.0000)$ * \\
\hline & $\ln Y_{i t}$ & $299.109(0.0000)$ * & $51.87097(0.0000)$ * & $17.26065(0.0000)$ * \\
\hline & $\ln T R_{i t}$ & $294.9485(0.0000)$ * & $51.11136(0.0000)$ * & $17.14719(0.0000)$ * \\
\hline & $\ln E C_{i t}$ & $136.8153(0.0000)$ * & $22.24034(0.0000)$ * & $2.180673(0.0000)$ * \\
\hline
\end{tabular}

\subsubsection{Panel Unit Root Test}

Our research employed two alternative unit root test approaches to examine the availability of stationarity in our panel data and to reduce the problem of inconsistency and invalid test statistics in our estimation. This included the Levin-Lin-Chu (LLC) approach by Levin et al. [61] and the Im-Pesaran-Shin (IPS) test by Im et al. [62] (Table 3). In this respect, the null hypothesis of nonstationarity within the series is evaluated against the alternative hypothesis that a proportion of the variables are completely static. Conversely, the LLC test for stationarity merges the various cross-sections, allowing the free movement of trends and intercepting coefficients across cross-sections and generating joint $t$-test results [63]. The LLC test evaluates the null hypothesis of stationarity between the individual cross-sections with the alternative hypothesis of stationarity between all cross-sections. According to Baltagi et al. [64], the LLC technique allows for "static influences, separate deterministic movements and unrelated serially correlated errors", providing efficient results for panels of a moderate size. To limit the impact of cross-sectional dependency in our panel, we demeaned the data during the LLC test. In addition, Bildirici et al. [65] confirmed that the LLC test provides better approximations compared to other previous stationarity test approaches.

Table 3. Unit root test result.

\begin{tabular}{cllll}
\hline \multirow{2}{*}{ Panels/Series } & \multicolumn{2}{c}{ Level } & \multicolumn{2}{c}{ First Difference } \\
\cline { 2 - 5 } & \multicolumn{1}{c}{ Intercept } & Intercept and Trend & \multicolumn{1}{c}{ Intercept } & Intercept and Trend \\
\hline Belt and Road & & & \\
\hline LLC Test & & & \\
$\ln C O_{2 i t}$ & $-3.422(0.0003) *$ & $-4.73(0.0000)^{*}$ & $-11.91(0.0000)^{*}$ & $-8.873(0.0000)^{*}$ \\
$\ln Y_{i t}^{*}$ & $0.894(0.8145)$ & $-1.680(0.0464)^{* *}$ & $-10.616(0.0000)^{*}$ & $-8.153(0.0000)^{*}$ \\
$\ln T R_{i t}$ & $-0.906(0.1823)$ & $-1.401(0.0805)^{* * *}$ & $-14.561(0.0000)^{*}$ & $-11.23(0.0000)^{*}$ \\
$\ln E C_{i t}^{* * *}$ & $-1.358(0.0872) * * *$ & $-1.285(0.0993)^{* * *}$ & $-9.154(0.0000)^{*}$ & $-7.365(0.0000)^{*}$ \\
\hline IPS Test & & & & \\
$\ln C O_{2 i t}$ & $0.857(0.8044)$ & $-1.475(0.0700)^{* * *}$ & $-15.574(0.0000)^{*}$ & $-12.97(0.0000)^{*}$ \\
$\ln Y_{i t}^{*}$ & $7.896(1.0000)$ & $0.296(0.6165)$ & $-11.242(0.0000)^{*}$ & $-6.881(0.0000)^{*}$ \\
$\ln T R_{i t}$ & $7.067(1.0000)$ & $-0.958(0.1689)$ & $-14.994(0.0000)^{*}$ & $-10.83(0.0000)^{*}$ \\
$\ln E C_{i t}$ & $-0.948(0.1715)$ & $-1.449(0.0736) * *$ & $-13.411(0.0000)^{*}$ & $-9.508(0.0000)^{*}$ \\
\hline
\end{tabular}


Table 3. Cont.

\begin{tabular}{|c|c|c|c|c|}
\hline \multirow{2}{*}{ Panels/Series } & \multicolumn{2}{|c|}{ Level } & \multicolumn{2}{|c|}{ First Difference } \\
\hline & Intercept & Intercept and Trend & Intercept & Intercept and Trend \\
\hline \multicolumn{5}{|l|}{ High-Income } \\
\hline \multicolumn{5}{|l|}{ LLC Test } \\
\hline $\ln \mathrm{CO}_{2 i t}$ & $-2.628(0.0043) *$ & $-0.613(0.2697)$ & $-7.7673(0.0000) *$ & $-5.677(0.0000) *$ \\
\hline $\ln Y_{i t}$ & $-0.711(0.2384)$ & $-0.028(0.4886)$ & $-9.1453(0.0000)$ * & $-7.705(0.0000) *$ \\
\hline $\ln T R_{i t}$ & $0.016(0.5067)$ & $-1.804(0.0356) * *$ & $-10.013(0.0000)$ * & $-8.107(0.0000) *$ \\
\hline $\ln E C_{i t}$ & $-0.347(0.3642)$ & $2.190(0.9860)$ & $-3.692(0.0001)^{*}$ & $-2.561(0.0052) *$ \\
\hline \multicolumn{5}{|l|}{ IPS Test } \\
\hline $\ln \mathrm{CO}_{2 i t}$ & $-1.097(0.1361)$ & $-0.072(0.4709)$ & $-10.264(0.0000) *$ & $-9.075(0.0000)$ * \\
\hline $\ln Y_{i t}$ & $3.740(0.9999)$ & $0.250(0.6003)$ & $-7.607(0.0000) *$ & $-5.051(0.0000) *$ \\
\hline $\ln T R_{i t}$ & $4.616(1.0000)$ & $-1.278(0.1005)$ & $-9.824(0.0000) *$ & $-7.54(0.0000)^{*}$ \\
\hline $\ln E C_{i t}$ & $-2.158(0.0154)^{* *}$ & $0.155(0.5620)$ & $-7.532(0.0000) *$ & $-5.66(0.0000) *$ \\
\hline \multicolumn{5}{|l|}{ Middle-Income } \\
\hline \multicolumn{5}{|l|}{ LLC Test } \\
\hline $\ln \mathrm{CO}_{2 i t}$ & $-3.277(0.0005) *$ & $-4.253(0.0000) *$ & $-8.146(0.0000) *$ & $-5.980(0.0000) *$ \\
\hline $\ln Y_{i t}^{2 i t}$ & $0.286(0.6129)$ & $-1.2978(0.0972)^{* * *}$ & $-5.611(0.0000) *$ & $-3.536(0.0002) *$ \\
\hline $\ln T R_{i t}$ & $-1.143(0.1264)$ & $-0.7078(0.2395)$ & $-10.484(0.0000)$ * & $-8.474(0.0000) *$ \\
\hline $\ln E C_{i t}$ & $-1.737(0.0411)^{* *}$ & $-2.705(0.0034) *$ & $-7.536(0.0000)^{*}$ & $-6.182(0.0000) *$ \\
\hline \multicolumn{5}{|l|}{ IPS Test } \\
\hline $\ln \mathrm{CO}_{2 i t}$ & $1.417(0.9218)$ & $-1.599(0.0549) * * *$ & $-10.692(0.0000)$ * & $-8.243(0.0000)$ * \\
\hline $\ln Y_{i t}$ & $5.503(1.0000)$ & $0.682(0.7525)$ & $-7.290(0.0000) *$ & $-3.83(0.0001)^{*}$ \\
\hline $\ln T R_{i t}$ & 4.952 (1.0000) & $0.050(0.5201)$ & $-9.859(0.0000) *$ & $-6.704(0.0000)^{*}$ \\
\hline $\ln E C_{i t}$ & $0.208(0.5826)$ & $-1.472(0.0705)^{* * *}$ & $-9.869(0.0000)$ * & $-6.598(0.0000) *$ \\
\hline \multicolumn{5}{|l|}{ Low-Income } \\
\hline \multicolumn{5}{|l|}{ LLC Test } \\
\hline $\ln \mathrm{CO}_{2 i t}$ & $0.818(0.7935)$ & $-2.654(0.004) *$ & $-2.440(0.0070) *$ & $-1.356(0.0874)^{* * *}$ \\
\hline $\ln Y_{i t}$ & $3.022(0.9987)$ & $-2.406(0.0081) *$ & $-5.154(0.0000) *$ & $-4.908(0.0000) *$ \\
\hline $\ln T R_{i t}$ & $-0.642(0.2602)$ & $-0.909(0.1815)$ & $-2.933(0.0017) *$ & $-0.524(0.3001)$ \\
\hline $\ln E C_{i t}$ & $0.371(0.6447)$ & $-1.908(0.0282)^{* *}$ & $-5.003(0.0000) *$ & $-4.837(0.0000)$ * \\
\hline \multicolumn{5}{|l|}{ IPS Test } \\
\hline $\ln \mathrm{CO}_{2 i t}$ & 1.335 (0.9091) & $-0.728(0.2332)$ & $-4.997(0.0000) *$ & $-4.645(0.0000) *$ \\
\hline $\ln Y_{i t}$ & 4.849 (1.0000) & $-0.950(0.1709)$ & $-4.118(0.0000)$ * & $-3.256(0.0006) *$ \\
\hline $\ln T R_{i t}$ & $1.854(0.9682)$ & $-0.821(0.2056)$ & $-5.579(0.0000) *$ & $-3.929(0.0000) *$ \\
\hline $\ln E C_{i t}$ & $0.518(0.6981)$ & $-1.303(0.0961)^{* * *}$ & $-5.026(0.0000)$ * & $-3.855(0.0001) *$ \\
\hline
\end{tabular}

Note: ${ }^{*}, * * * *$ indicates significance at $1 \%, 5 \%$, and $10 \%$ respectively. LLC: Levin-Lin-Chu, IPS: Im-Pesaran-Shin.

\subsubsection{Panel Cointegration Test}

Several panel cointegration tests are available in the literature, and the emergence of a panel cointegration test from time series analysis is a recent occurrence. We therefore used seven different test statistics for testing the cointegration nexus in the heterogeneous panels described by Pedroni [27]. This test was further grouped into two dimensions: the "inner dimension" and "between dimensional statistics", usually described as the panel cointegration test and grouped mean panel cointegration statistics, respectively. The alternative hypotheses for both groups were tested against the same null hypothesis. However, this analysis was modified to minimize the possible bias created by the potential endogenous series in the model. When applying the cointegration test by Pedroni [27], we first evaluated the panel cointegration regression model and saved the residual:

$$
X_{i t}=\delta_{o i}+\alpha_{i} t+\beta_{1 i} Y_{1 i t}+\beta_{n i} Y_{n i t}+\pi_{i t} .
$$


We continued the test by finding the first difference of our dataset for the 49 selected countries and calculated the residuals of the differentiated regression as below:

$$
\Delta X_{i t}=\theta_{1 i} \Delta Y_{1 i t}+\theta_{n i} \Delta Y_{n i t}+\varepsilon_{i t}
$$

The third sequence of the test was to estimate the residual $\left(\hat{\varepsilon}_{i t}\right)$ and the long-run variance $\left(\hat{L}_{11 i}^{2}\right)$ using the regression equation developed after estimating our first difference. This was then followed by estimating the appropriate autoregressive model using the residuals from the panel cointegration regression equation. The next step was to calculate the seven-panel statistics developed by [27] using the averages and variance modification. All seven tests by Pedroni [27] verified the null hypothesis of no cointegration (Table 4). This is computed below versus different alternative hypotheses, $H_{1}: \rho_{i}=1$ for all $i=1,2,3 \ldots \ldots \ldots N$. The alternative hypothesis for the grouped mean panel cointegration statistics was $H_{1}: \rho_{i}<1$, where a similar value of $\rho_{i}=\rho$ was insignificant. Similarly, the alternative hypothesis for the "inner dimension" was $\rho_{i}=\rho<1$. Here, we presumed a constant value for $\rho_{i}=\rho$. However, with respect to the various alternative hypotheses, the outcomes were negative.

Table 4. Pedroni cointegration test result.

\begin{tabular}{|c|c|c|c|c|c|c|c|}
\hline Model & Panels & Statistics & $P$-Value & Model & Panels & Statistic & $P$-Value \\
\hline Within-Dimension & & & & Within-Dimension & & & \\
\hline Panel v-Statistic & & 2.7042 & $0.0034 *$ & Panel v-Statistic & & 0.7829 & 0.2168 \\
\hline Panel rho-Statistic & & -2.7354 & $0.0031 *$ & Panel rho-Statistic & & -0.3463 & 0.3646 \\
\hline $\begin{array}{l}\text { Panel ADF-Statistic } \\
\text { Between-Dimension }\end{array}$ & Belt and Road & -2.4385 & $0.0074 *$ & $\begin{array}{l}\text { Panel ADF-Statistic } \\
\text { (Between-Dimension) }\end{array}$ & High-Income & -2.2013 & $0.0139 * *$ \\
\hline Group rho-Statistic & & 0.6731 & 0.7496 & Group rho-Statistic & & 0.1584 & 0.5630 \\
\hline Within-Dimension & & & & Within-Dimension & & & \\
\hline Panel v-Statistic & & 2.5904 & $0.0048 *$ & Panel v-Statistic & & 3.9026 & $0.0000 *$ \\
\hline Panel rho-Statistic & & -3.4590 & $0.0003 *$ & Panel rho-Statistic & & -1.7520 & $0.0399 * *$ \\
\hline Panel PP-Statistic & & -9.4382 & $0.0000 *$ & Panel PP-Statistic & & -3.9126 & 0.0000 * \\
\hline $\begin{array}{l}\text { Panel ADF-Statistic } \\
\text { Between-Dimension }\end{array}$ & Middle-Income & -1.3362 & $0.0907^{* * *}$ & $\begin{array}{l}\text { Panel ADF-Statistic } \\
\text { Between-Dimension }\end{array}$ & Low-Income & -1.8888 & $0.0295^{* *}$ \\
\hline
\end{tabular}

Note: ${ }^{*}, * * * *$ indicates significance at $1 \%, 5 \%$, and $10 \%$, respectively (authors' computation). ADF: augmented Dickey-Fuller; PP: Phillips-Perron.

\subsubsection{Panel Cointegration Estimates}

In this section, we examine the long-run effects between our dependent and independent variables considering the existence of cross-sectional dependency within our dataset. We estimated the long-run regression models by means of the FMOLS technique (Table 5). The FMOLS is totally independent from larger samples within the existence of endogeneity and heterogeneous changes. Once more, using this approach generates consistent and unbiased estimates in smaller samples [66]. The FMOLS coefficient estimator is defined below:

$$
\hat{\beta}_{N T}^{*}=N^{-1 / 2} \sum_{i=1}^{N} \hat{V}_{11 i}^{-1}\left(\sum_{t=1}^{T}\left(y_{i t}-\bar{y}_{i}\right)^{2}\right)^{-1 / 2}\left(\sum_{t=1}^{T}\left(y_{i t}-\bar{y}_{i}\right)\right) X_{i t}^{*}-T \hat{\varepsilon}_{i},
$$

where $X_{i t}^{*}=\left(X_{i t}-\bar{X}\right)-\frac{\hat{V}_{21 t}}{\bar{V}_{22 i}} \Delta y_{i t}, \hat{\varepsilon}_{i}=\hat{G}_{21 i}+\hat{\vartheta}_{21 i}^{0}-\frac{\hat{V}_{21 t}}{\bar{V}_{22 i}}\left(\hat{G}_{22 i}+\hat{\vartheta}_{22 i}^{0}\right)$, and $\hat{V}_{i}$ is a lower triangular decomposition of $\hat{\vartheta}_{i}$ as both $T$ and $N$ approach infinity for both the standard model lacking intercepts and the fixed effects model with heterogeneous intercepts. 
Table 5. Panel FMOLS cointegration estimate results.

\begin{tabular}{|c|c|c|c|c|c|}
\hline \multicolumn{6}{|c|}{ Dependent Variable $\ln \mathrm{CO}_{2 i t}$} \\
\hline Panel/Variables & Coefficient & $P$-Value & Panel/Variable & Coefficient & $P$-Value \\
\hline Belt and Road & & & Southeast Asia & & \\
\hline $\ln Y_{i t}$ & -0.2055 & $0.0000 *$ & $\ln Y_{i t}$ & 0.1306 & $0.0000 *$ \\
\hline $\ln T R_{i t}$ & 0.2240 & $0.0000 *$ & $\ln T R_{i t}$ & 0.2368 & 0.0000 * \\
\hline $\ln E C_{i t}$ & 1.1648 & $0.0000 *$ & $\ln E C_{i t}$ & 0.7464 & $0.0000 *$ \\
\hline High-Income & & & Central Asia & & \\
\hline $\ln Y_{i t}$ & -0.5800 & $0.0000 *$ & $\ln Y_{i t}$ & 0.0576 & $0.0303^{* *}$ \\
\hline $\ln T R_{i t}$ & 0.4623 & $0.0000 *$ & $\ln T R_{i t}$ & 0.1174 & $0.0596^{* * *}$ \\
\hline $\ln E C_{i t}$ & 1.1857 & $0.0000 *$ & $\ln E C_{i t}$ & 0.7558 & $0.0000 *$ \\
\hline Middle-Income & & \multicolumn{4}{|c|}{ Middle East/Africa } \\
\hline $\ln Y_{i t}$ & -0.0488 & $0.0000 *$ & $\ln Y_{i t}$ & -0.0773 & $0.0002 *$ \\
\hline $\ln T R_{i t}$ & 0.0471 & $0.0124^{* *}$ & $\ln T R_{i t}$ & 0.3314 & $0.0000 *$ \\
\hline $\ln E C_{i t}$ & 1.2701 & $0.0000 *$ & $\ln E C_{i t}$ & 0.6140 & 0.0000 * \\
\hline Low-Income & & & South Asia & & \\
\hline $\ln Y_{i t}$ & 0.0989 & $0.0000 *$ & $\ln Y_{i t}$ & 0.2209 & 0.0000 * \\
\hline $\ln T R_{i t}$ & 0.3090 & $0.0000 *$ & $\ln T R_{i t}$ & 0.1861 & 0.0001 * \\
\hline $\ln E C_{i t}$ & 1.096 & 0.0000 * & $\ln E C_{i t}$ & 1.2633 & 0.0000 * \\
\hline East Asia & & & Europe & & \\
\hline $\ln Y_{i t}$ & 0.3728 & $0.0000 *$ & $\ln Y_{i t}$ & 0.0666 & $0.0000 *$ \\
\hline $\ln T R_{i t}$ & -0.1172 & 0.2625 & $\ln T R_{i t}$ & -0.1407 & 0.0000 * \\
\hline $\ln E C_{i t}$ & 0.6835 & $0.0000 *$ & $\ln E C_{i t}$ & 1.1414 & 0.0000 * \\
\hline
\end{tabular}

Note: ${ }^{*}, * *, * * *$ indicates significance at $1 \%, 5 \%$, and $10 \%$, respectively. FMOLS: Fully Modified Ordinary Least Squares.

\subsubsection{Panel Causality Test}

After estimating the long-run nexus between the underlined series, we followed Engle et al. [26] to examine the Granger causality between sustainable trade and pollution using the vector error correction model (VECM) panel model (Tables 6 and 7). Our VECM model is defined below:

$$
\begin{gathered}
\Delta \ln C O_{2 i t}=\delta_{i}+\sum_{j=1}^{n} \delta_{11 i j} \Delta \ln C O_{2 i, t-j}+\sum_{j=1}^{n} \delta_{12 i j} \Delta \ln Y_{i, t-j}+\sum_{j=1}^{n} \delta_{13 i j} \Delta \ln T R_{i, t-j}+ \\
\sum_{j=1}^{n} \delta_{14 i j} \Delta \ln E C_{i, t-j}+\gamma_{1 i} \theta_{i, t-1}+\varepsilon_{i t},
\end{gathered}
$$

where $\gamma_{1 i}$ represents the elasticity of adjustment for the cointegration vector $\theta_{i, t-1}$; and $\delta_{12 i j}, \delta_{13 i j}, \theta_{14 i j}$ indicate the short-term elasticity for the break values of the endogenous series, that is, economic growth, international trade, and energy usage, respectively. We employed Wald tests ( $F$-tests) for short-run causality to test the null hypotheses of $H_{0}=\delta_{12 i j}=0$ for every $i$ and $j$ in our equation. Similarly, the null hypothesis of $H_{0}=\gamma_{1 i}=0$ was used to estimate the long-term causal relationship between the selected variables for all $i$ and $j$ in the equation. Utilizing the multiple regression causal relationships proposed by Granger with a break interval of $n$ (Schwarz Info Criterion, SIC $=2$ ), we estimated and analyzed the direction of both causalities within our model.

Table 6. Panel vector error correction model (VECM) Granger causality test results.

\begin{tabular}{cccccc}
\hline & \multicolumn{5}{c}{ Independent Variables } \\
\cline { 2 - 6 } Dependent Variables & \multicolumn{1}{c}{$\ln C \boldsymbol{O}_{2 i t}$} & $\ln Y_{i t}$ & $\ln T R_{i t}$ & $\ln E C_{i t}$ & ECT-1 \\
\cline { 2 - 6 } & \multicolumn{5}{c}{ Short Run } \\
\hline Belt and Road & 0 & $1.2487(0.5356)$ & $2.9302(0.2310)$ & $17.3300(0.0002)^{*}$ & $-0.0079(0.0000)^{*}$ \\
$\ln C O_{2 i t}$ & $1.6195(0.4450)$ & 0 & $0.3005(0.8605)$ & $18.6802(0.0001)^{*}$ & $0.0011(0.5428)$ \\
$\ln Y_{i t}$ & $0.3517(0.8387)$ & $3.7997(0.1496)$ & 0 & $14.3249(0.0008)^{*}$ & $0.0025(0.2859)$ \\
$\ln T R_{i t}$ & $13.3974(0.0012)^{*}$ & $0.4795(0.7868)$ & $0.0925(0.9548)$ & 0 & $-0.0022(0.0320)^{* *}$ \\
$\ln E C_{i t}^{*}$
\end{tabular}


Table 6. Cont.

\begin{tabular}{|c|c|c|c|c|c|}
\hline \multirow{3}{*}{ Dependent Variables } & \multicolumn{5}{|c|}{ Independent Variables } \\
\hline & $\ln C \mathrm{O}_{2 i t}$ & $\ln Y_{i t}$ & $\ln T R_{i t}$ & $\ln E C_{i t}$ & ECT-1 \\
\hline & \multicolumn{4}{|c|}{ Short Run } & Long Run \\
\hline \multicolumn{6}{|l|}{ High-Income } \\
\hline $\ln \mathrm{CO}_{2 i t}$ & 0 & $1.3830(0.5008)$ & $1.2084(0.5465)$ & $12.3981(0.0020)$ * & $-0.0094(0.0008)$ * \\
\hline $\ln Y_{i t}$ & $1.0366(0.5955)$ & 0 & $0.7134(0.7000)$ & $10.3203(0.0057)$ * & $-0.0082(0.0120) * *$ \\
\hline $\ln T R_{i t}$ & $0.8481(0.6544)$ & $0.0086(0.9957)$ & 0 & 3.5804 (0.1669) & $0.0028(0.5079)$ \\
\hline $\ln E C_{i t}$ & $4.3611(0.1130)$ & $1.1299(0.5684)$ & $2.3906(0.3026)$ & 0 & $0.0024(0.2079)$ \\
\hline \multicolumn{6}{|l|}{ Middle-Income } \\
\hline $\ln \mathrm{CO}_{2 i t}$ & 0 & $0.3361(0.8453)$ & $5.0801(0.0789)^{* * *}$ & $6.5886(0.0371) * *$ & $-0.0031(0.0000)$ * \\
\hline $\ln Y_{i t}^{2 n t}$ & $2.0913(0.3514)$ & 0 & $1.6337(0.4418)$ & $8.3475(0.0154) * *$ & 0.0001 (0.9209) \\
\hline $\ln T R_{i t}$ & $0.1346(0.9349)$ & $7.0280(0.0298) * *$ & 0 & $7.9989(0.0183) * *$ & $-0.0002(0.8139)$ \\
\hline $\ln E C_{i t}$ & $25.6053(0.0000)^{*}$ & $1.7689(0.4129)$ & $0.7490(0.6876)$ & 0 & $-0.0010(0.0065)^{*}$ \\
\hline \multicolumn{6}{|l|}{ Low-Income } \\
\hline $\ln \mathrm{CO}_{2 i t}$ & 0 & $1.4921(0.4742)$ & $7.2661(0.0264) * *$ & $6.8192(0.0331) * *$ & $-0.0536(0.0000) *$ \\
\hline $\ln Y_{i t}$ & $2.3161(0.3141)$ & 0 & $0.6581(0.7196)$ & $6.3442(0.0419) * *$ & $-0.0149(0.1480)$ \\
\hline $\ln T R_{i t}$ & $2.9359(0.2304)$ & $0.4687(0.7910)$ & 0 & $4.3696(0.1125)$ & $-0.0163(0.2986)$ \\
\hline $\ln E C_{i t}$ & $1.4947(0.4736)$ & $0.8927(0.6399)$ & $1.6468(0.4389)$ & 0 & $-0.0281(0.0002)$ * \\
\hline \multicolumn{6}{|l|}{ East Asia } \\
\hline $\ln \mathrm{CO}_{2 i t}$ & 0 & $1.3295(0.5144)$ & $0.7680(0.6811)$ & $0.4543(0.7968)$ & $-0.0901(0.2115)$ \\
\hline $\ln Y_{i t}$ & $5.6673(0.0588) * * *$ & 0 & $1.4974(0.4730)$ & $8.8903(0.0117) * *$ & $0.0173(0.7982)$ \\
\hline $\ln T R_{i t}$ & $7.3016(0.0260) * *$ & $4.6727(0.0967)^{* * *}$ & 0 & $6.0167(0.0494) * *$ & $-0.1629(0.0378)$ ** \\
\hline $\ln E C_{i t}$ & $1.6397(0.4405)$ & $8.5985(0.0136) * *$ & $7.2096(0.0272) * *$ & 0 & $-0.0811(0.0004)$ * \\
\hline \multicolumn{6}{|l|}{ Southeast Asia } \\
\hline $\ln \mathrm{CO}_{2 i t}$ & 0 & $2.0055(0.3669)$ & $0.7635(0.6827)$ & $4.9328(0.0849) * * *$ & $0.0085(0.1926)$ \\
\hline $\ln Y_{i t}$ & $0.9883(0.6101)$ & 0 & $0.7069(0.7022)$ & $0.6981(0.7053)$ & $0.0015(0.8169)$ \\
\hline $\ln T R_{i t}$ & $2.0244(0.3634)$ & $15.23863(0.0005)$ * & 0 & $0.9334(0.6270)$ & $0.0268(0.0001)$ \\
\hline $\ln E C_{i t}$ & $12.5851(0.0018)$ * & $2.7928(0.2475)$ & $0.9591(0.6190)$ & 0 & $0.0015(0.6956)$ \\
\hline \multicolumn{6}{|l|}{ Central Asia } \\
\hline $\ln \mathrm{CO}_{2 i t}$ & 0 & $2.3240(0.3129)$ & $5.3926(0.0675) * * *$ & $11.7651(0.0028)$ * & $0.0077(0.7782)$ \\
\hline $\ln Y_{i t}$ & 3.4059 (0.1821) & 0 & $0.7016(0.7041)$ & $3.5999(0.1653)$ & $0.0548(0.0646)$ \\
\hline $\ln T R_{i t}$ & $10.5200(0.0052)$ * & $5.6221(0.0601)^{* * *}$ & 0 & $8.1708(0.0168) * *$ & $-0.0897(0.0325) * *$ \\
\hline $\ln E C_{i t}$ & $2.9591(0.2277)$ & $3.0529(0.2173)$ & $0.1795(0.9142)$ & 0 & $0.0104(0.5874)$ \\
\hline
\end{tabular}

Note: ${ }^{*}, * * * * *$ indicates significance at $1 \%, 5 \%$, and $10 \%$, respectively (authors ${ }^{\prime}$ computation).

Table 7. Panel VECM Granger causality test results.

\begin{tabular}{|c|c|c|c|c|c|}
\hline \multirow{3}{*}{ Dependent Variables } & \multicolumn{5}{|c|}{ Independent Variables } \\
\hline & $\ln C \mathrm{O}_{2 i t}$ & $\ln Y_{i t}$ & $\ln T R_{i t}$ & $\ln E C_{i t}$ & ECT-1 \\
\hline & \multicolumn{4}{|l|}{ Short Run } & Long Run \\
\hline \multicolumn{6}{|l|}{ Middle East/Africa } \\
\hline $\ln \mathrm{CO}_{2 i t}$ & 0 & $4.7957(0.0909)^{* * *}$ & $6.3626(0.0415) * *$ & $6.5713(0.0374) * *$ & $0.0001(0.9906)$ \\
\hline $\ln Y_{i t}$ & $1.1447(0.5642)$ & 0 & $0.2670(0.8750)$ & $12.8194(0.0016) *$ & $0.0058(0.6935)$ \\
\hline $\ln T R_{i t}$ & $0.0507(0.9749)$ & $4.8561(0.0882) * * *$ & 0 & $3.1981(0.2021)$ & $0.0327(0.1114)$ \\
\hline $\ln E C_{i t}$ & $1.3344(0.5131)$ & $1.2602(0.5325)$ & $2.1999(0.3329)$ & 0 & $0.0034(0.7136)$ \\
\hline \multicolumn{6}{|l|}{ South Asia } \\
\hline $\ln \mathrm{CO}_{2 i t}$ & 0 & $0.5075(0.7759)$ & $2.4841(0.2888)$ & $1.5018(0.4719)$ & $0.0002(0.5460)$ \\
\hline $\ln Y_{i t}$ & $0.1256(0.9391)$ & 0 & $1.4524(0.4837)$ & $1.4525(0.4837)$ & $-0.0001(0.9709)$ \\
\hline $\ln T R_{i t}$ & $1.0750(0.5842)$ & $7.7166(0.0211)^{* *}$ & 0 & $3.0753(0.2149)$ & $0.0013(0.0204)$ \\
\hline $\ln E C_{i t}$ & $1.3776(0.5022)$ & $2.7386(0.2543)$ & $2.8025(0.2463)$ & 0 & $0.0004(0.0095)$ \\
\hline \multicolumn{6}{|l|}{ Europe } \\
\hline $\ln \mathrm{CO}_{2 i t}$ & 0 & $0.3553(0.8372)$ & $6.6823(0.0354) * *$ & $4.1866(0.1233)$ & $-0.0169(0.0046) *$ \\
\hline $\ln Y_{i t}$ & $2.9953(0.2237)$ & 0 & $0.1447(0.9302)$ & $4.8213(0.0898)^{* * *}$ & $-0.0283(0.0032) *$ \\
\hline $\ln T R_{i t}$ & $1.6183(0.4452)$ & $1.5161(0.4686)$ & 0 & $3.1959(0.2023)$ & $0.0115(0.3078)$ \\
\hline $\ln E C_{i t}$ & $32.4836(0.0000) *$ & $3.2300(0.1989)$ & $5.8535(0.0536) * * *$ & 0 & $0.0116(0.0061)$ \\
\hline
\end{tabular}

Note: $* * * * * *$ indicates significance at $1 \%, 5 \%$, and 10\%, respectively (authors' computation). ECT: Error Correction Term.

\section{Results and Discussions}

This section discusses the empirical outcomes of the analysis. Table 2 displays the outcomes of the cross-sectional dependency test applied to both the dependent and independent variables using the 
approaches of Pesaran et al. [58,59], and Breusch et al. [60]. Based on our results, we rejected the null hypothesis of the cross-sectional dependency test for the underlined variables. Subsequently, a unit root test was performed to check for stationarity and to determine the integrative features of the data using the LLC statistics of Levin et al. [61] and then the IPS test statistics of Im et al. [62]. The results for these tests are reported in Table 3 for all variables, indicating that $\mathrm{CO}_{2}$ emissions, trade openness, real income, and energy usage were nonstationary in level form. On the other hand, in the first difference, all variables were integrated, explaining that pollution, real income, trade, and energy usage had a distinctive order of integration in each panel. This result helped in investigating the long-term nexus between the series using the panel cointegration technique. Estimates from the panel cointegration test are shown in Table 4 using the panel cointegration test developed by Pedroni [27]. The outcome shows that we accepted the alternative hypothesis of cointegration in most circumstances. Therefore, we conclude by saying that there was ample proof for the existence of cointegrating relationships between the variables (trade openness, economic growth, energy usage, and environmental quality). The results of the panel FMOLS analysis of the long-term effects between real income, energy consumption, and trade on environmental pollution are stated in Table 5. The empirical results showed that trading with the global economy significantly increased environmental pollution in Belt and Road countries (1\%), developed economies $(1 \%)$, developing economies $(5 \%)$, underdeveloped economies $(1 \%)$, Southeast Asia $(1 \%)$, Central Asia (10\%), the Middle East/Africa (1\%), and South Asia (1\%). This implies that a percentage increase in international trade increased environmental pollution by the various magnitudes of the trade coefficients, keeping the other explanatory variables constant. This result is in line with findings from Shahbaz et al. [6] and Managi et al. [36]. A potential explanation for this impact of trade on the environment could be a heavy reliance on coal-powered technologies for production, household energy consumption, and the numerous pollution industries located within these regions, with patterns of specialty in high-pollutant commodities, hence providing support for the pollution haven hypothesis.

However, the coefficient of trade openness was inverse and statistically significant in Europe (1\%), but was not significant in East Asia. This implies that increasing trade with the global world reduced emissions in Europe and East Asia, but the effect was insignificant in East Asia. Countries within this panel were relocating their dirty industries to emerging economies with lenient or nonexistent environmental regulations. Economic growth had a negative impact on $\mathrm{CO}_{2}$ emissions in the Belt and Road countries $(1 \%)$, high-income countries $(1 \%)$, middle-income countries $(1 \%)$, and in the Middle East/Africa (1\%). This means that a percentage increase in economic growth reduced pollution in the atmosphere by a percentage of the growth elasticity in the various panels, hence improving the quality of the environment. Countries within these panels should concentrate on expanding growth in an attempt to reduce environmental pollution. This confirms the result of Frankel et al. [67]. Similarly, the panel results indicated a positive significant impact of real income on $\mathrm{CO}_{2}$ emissions in low-income countries (1\%), Southeast Asia (1\%), South Asia (1\%), Central Asia (5\%), East Asia $(1 \%)$, and Europe $(1 \%)$. This implies that a $1 \%$ increase in real income (holding the other control variables constant) increased the $\mathrm{CO}_{2}$ level in the atmosphere by a percentage magnitude of the growth coefficient. This result is in line with the past outcomes of Omri [33] and Fodha et al. [48].

Since increasing economic growth involves the expansion of economic activities, the level of energy usage increases alongside growth. Consequently, the byproducts of energy consumption emit pollution into the atmosphere, therefore reducing environmental quality. The coefficient of energy consumption was positive and significant for the Belt and Road countries (1\%), high-income nations $(1 \%)$, middle-income countries (1\%), low-income countries (1\%), East Asia (1\%), South Asia (1\%), Southeast Asia(1\%), the Middle East/Africa(1\%), Central Asia(1\%), and Europe(1\%).This implies that a $1 \%$ increase in energy consumption (holding the other explanatory variables constant) increased $\mathrm{CO}_{2}$ emissions levels in the atmosphere by a percentage magnitude of the energy consumption coefficient. Our results were consistent with previous studies [38]. This confirmed our anticipated outcomes, since according to the literatures; increasing energy usage reduces environmental quality in the long run: this result was related to the $\mathrm{PHH}$. The dirty industry relies heavily on conventional energy 
sources (mainly coal power) for production, since most of these economies are now developing their clean energy sectors. The U.S. Energy Information Administration (2013) has reported China as the largest energy consumer worldwide, with a total energy use of 113,200 trillion British thermal units, accounting for about $22 \%$ of global energy usage. About $71 \%$ of total energy consumption is generated by coal, followed by oil $(19 \%)$, hydroelectric power $(6 \%)$, natural gas $(3 \%)$, nuclear energy $(1 \%)$, and other clean energy $(0.2 \%)$. In addition, the output of the panel VECM Granger causality results (reported in Tables 6 and 7) indicated a long-run relationship between real income, trade openness, energy usage, and $\mathrm{CO}_{2}$ emissions in the Belt and Road panel, with a feedback effect between energy consumption and $\mathrm{CO}_{2}$ emissions both in the short run and long run. This implies that there was a bidirectional relationship between energy consumption and $\mathrm{CO}_{2}$ emissions.

Similarly, the panel VECM Granger causality outcomes for the high-income, middle-, and low-income groups displayed a long-run relationship between real income, trade openness, energy consumption, and $\mathrm{CO}_{2}$ emissions. Trade openness and energy consumption Granger-caused $\mathrm{CO}_{2}$ emissions in the middle- and low-income panels in the short run. Likewise, there was a feedback relationship between $\mathrm{CO}_{2}$ emissions and energy consumption in the middle-income panel in the short run. This result supports the outcomes of Ozturk et al. [68] and Mardani et al. [69] and many others. In addition, the results showed long-run causality between real income, energy consumption, trade, and environmental pollution in the European panel, with a feedback effect between trade and energy consumption in the short run. Further, the negative coefficient of the square of trade openness in our EKC outcome confirmed the existence of an inverted U-shaped nexus between trade and environmental pollution in all 10 panels, but with different turning points. This ensured absolute environmental enhancement along the path of trade openness and globalization. Our EKC results confirmed the outcome of Omri [33].This result implies that as countries within this group expanded their economies into the global world, $\mathrm{CO}_{2}$ emissions initially increased and began to fall after the maximum trade threshold point was achieved.

Since the expansion of trade is influenced by increasing real income, we could relate this outcome to support the EKC framework, which tests the relationship between income and environmental quality. These trade turning points where emissions began to fall are reported in Table 8. Our findings showed that the EKC theory was supported in both developed and developing countries. However, it took more years for developing economies to reach the turning point than it took developed countries. Obtaining this threshold level was possible in the very short run through joint international efforts and supports. Generally, emissions from developing countries continued to rise until they reached the maximum turning point, making them the largest emitters of global $\mathrm{CO}_{2}$ emissions. Our results confirmed the rising levels of emissions, specifically $\mathrm{CO}_{2}$, in developing economies such as China and India. According to the EKC theory, until these countries reach the maximum turning point, their emissions levels continue to increase as their economies grow. Countries are therefore adopting clean energy production technologies and consumption techniques that will promote economic growth and also reduce pollution and achieve a low-carbon economy. Higher turning points imply that it took countries within that panel fewer years to reach the threshold point where trade was maximized.

Table 8. Environmental Kuznets curve (EKC) results.

\begin{tabular}{cccccc}
\hline \multicolumn{5}{c}{ Dependent Variable $\operatorname{lnCO_{2it}}$} \\
\hline Variable & Coefficient & $\boldsymbol{P}$-Value & Variable & Coefficient & P-Value \\
\hline & Belt and Road & & & Southeast Asia & \\
$\ln Y_{i t}$ & -1.1147 & $0.0000^{*}$ & $\ln Y_{i t}$ & -1.4538 & $0.0000^{*}$ \\
$\ln T R_{i t}$ & 1.5184 & $0.0000^{*}$ & $\ln T R_{i t}$ & 2.555 & $0.0003^{*}$ \\
$\ln T R_{i t}^{2}$ & -0.0590 & $0.0000^{*}$ & $\ln T R_{i t}^{2}$ & -0.0814 & 0.1389 \\
$\ln E C_{i t}^{*}$ & 1.0489 & $0.0000^{*}$ & $\ln E C_{i t}$ & 0.8257 & $0.0000^{*}$ \\
Turning point & USD 386,314 & & Turning point & USD 8,612,713.642 \\
\hline
\end{tabular}


Table 8. Cont.

\begin{tabular}{|c|c|c|c|c|c|}
\hline \multicolumn{6}{|c|}{ Dependent Variable $\ln \mathrm{CO}_{2 i t}$} \\
\hline Variable & Coefficient & $P$-Value & Variable & Coefficient & $P$-Value \\
\hline & High-Income & & & Central Asia & \\
\hline $\ln Y_{i t}$ & -1.2342 & $0.0000 *$ & $\ln Y_{i t}$ & 0.1865 & $0.0003 *$ \\
\hline $\ln T R_{i t}$ & 1.5347 & $0.0000 *$ & $\ln T R_{i t}$ & 1.5288 & $0.0000 *$ \\
\hline $\ln T R_{i t}^{2}$ & -0.0710 & $0.0000 *$ & $\ln T R_{i t}^{2}$ & -0.0639 & 0.0000 * \\
\hline $\ln E C_{i t}^{i t}$ & 1.0448 & 0.0000 * & $\ln E C_{i t}^{i t}$ & 0.9160 & 0.0000 * \\
\hline Turning point & USD 57,362.316 & & Turning point & USD 338,856.956 & \\
\hline \multicolumn{3}{|c|}{ Middle-Income } & \multicolumn{3}{|c|}{ Middle East/Africa } \\
\hline $\ln Y_{i t}$ & -1.0986 & $0.0000 *$ & $\ln Y_{i t}$ & -1.1413 & 0.0000 * \\
\hline $\ln T R_{i t}$ & 1.11871 & $0.0001 *$ & $\ln T R_{i t}$ & 1.4808 & $0.0293 * *$ \\
\hline $\ln T R_{i+}^{2}$ & -0.0647 & 0.9370 & $\ln T R_{i+}^{2}$ & -0.0633 & 0.6470 \\
\hline $\ln E C_{i t}^{i t}$ & 0.9985 & $0.0000 *$ & $\ln E C_{i t}^{i t}$ & 0.9209 & 0.0000 * \\
\hline Turning point & USD 6212.84 & & Turning point & USD 227,142.60 & \\
\hline \multicolumn{3}{|c|}{ Low-Income } & \multicolumn{3}{|c|}{ South Asia } \\
\hline $\ln Y_{i t}$ & 0.3320 & $0.0799 * * *$ & $\ln Y_{i t}$ & -1.4674 & 0.0000 * \\
\hline $\ln T R_{i t}$ & -1.3137 & $0.0000 *$ & $\ln T R_{i t}$ & 8.7983 & 0.0000 * \\
\hline $\ln T R_{i t}^{2}$ & 0.0785 & $0.0000 *$ & $\ln T R_{i+}^{2}$ & -0.3481 & 0.0000 * \\
\hline $\ln E C_{i t}^{u}$ & -0.3756 & $0.0545^{* * *}$ & $\ln E C_{i t}^{i t}$ & 0.5951 & 0.0000 * \\
\hline Turning point & USD 4521.805 & & Turning point & USD 308,909.7981 & \\
\hline \multicolumn{3}{|c|}{ East Asia } & \multicolumn{3}{|c|}{ Europe } \\
\hline $\ln Y_{i t}$ & -1.0646 & $0.0000 *$ & $\ln Y_{i t}$ & -1.1622 & 0.0000 * \\
\hline $\ln T R_{i t}$ & 1.8589 & $0.0002 *$ & $\ln T R_{i t}$ & 1.5937 & 0.0003 * \\
\hline $\ln T R_{i t}^{2}$ & -0.1144 & 0.1164 & $\ln T R_{i t}^{2}$ & -0.0990 & 0.3096 \\
\hline $\ln E C_{i t}^{u}$ & 0.6946 & $0.0792 * * *$ & $\ln E C_{i t}^{u}$ & 0.0617 & 0.0000 * \\
\hline Turning point & USD 3460.3423 & & Turning point & USD 3119.582 & \\
\hline
\end{tabular}

\section{Conclusions and Policy Implications}

This research investigated the relationship between international trade and pollution (modeled as $\mathrm{CO}_{2}$ emissions), introducing other key explanatory variables such as energy consumption and economic growth and utilizing panels from 49 high-emission countries in Belt and Road regions. We further categorized these countries into regions and income groups for robust analysis. Data for these studies were collected from the World Development Indicators (2017). The data spanned a period of 24 years from 1991 to 2014, and participation in the WTO and data availability was considered. We employed a current panel estimation method for the empirical study. The stationarity and cross-sectional dependency test results showed that our selected variables were cointegrated at the first difference and were cross-sectionally dependent. Similarly, the cointegration test result confirmed that $\mathrm{CO}_{2}$ emissions, international trade, real income, and energy consumption were integrated in the long run. In addition, the panel results using the FMOLS method showed that trading with the global world significantly increased $\mathrm{CO}_{2}$ emissions in the Belt and Road, developed, developing, underdeveloped, Southeast Asia, Central Asia, the Middle East/Africa, and South Asia panels. Therefore, the outcomes of Copeland et al. [28] were confirmed, while East Asia and Europe showed an inverse significant relationship between trade and $\mathrm{CO}_{2}$ emissions. However, a significant fraction of these negative effects on environmental quality is expected to be offset by the recent path of increasing renewable energy consumption by firms and households, therefore providing support for the scale effect. The outcomes for the Belt and Road, developed, developing, and underdeveloped panels reaffirmed the common concept that developed nations dump emissions linked to their production in developing economies. They relocate their pollutant industries to these areas, providing support to the pollution haven hypothesis [28]. This external relocation improves the environment in industrialized economies, but continues to enhance economic growth and worsen the environment in emerging 
economies. However, with increased technical foreign direct investment from industrialized economies, the adverse ecological impacts of the scale effect in emerging countries can be minimized.

For example, foreign direct investment from developed countries has significantly transformed China into a highly contaminated manufacturer globally: then they export most of what they produce back to developed countries. The panel VECM Granger causality results showed that trade openness Granger-caused environmental pollution in the Belt and Road, developed, developing, underdeveloped, and European countries in the long run. This implies that the world's environment becomes better as the quality of the environment in the various income groups (high, middle, and low) improves. Hence, involving the various income groups and regions is necessary when establishing world environmental policies. The early trade and environmental policies observed in multilateral climate change agreements have failed to yield the desired outcome. This includes the Doha Climate Change Conference in 2012. Since then, researchers and environmental economists have taken a different approach to examining this issue. Our result confirmed the various past outcomes of Copeland et al. [28] and Frankel et al. [67]. In addition, different income groups have various propensities to influence environmental quality via open trade. This calls for various policy implications and the need for various policy techniques for improving environmental quality and enhancing economic growth sustainability. For instance, the greening investment principle is aimed at ensuring eco-friendliness, global warming adaptability, economic diversity, and inclusion. It demands that nations "green" their fiscal, budgetary, and monetary systems, as well as create strict climate change policies and enhance their implementation, creating green jobs through the provision of supportive fiscal and tax reforms, building green investment regulations and products, and promoting financial reporting for the whole supply chain system. However, this requires cooperation from stakeholders and beneficiaries. Countries must therefore develop a favorable and supportive environment for eco-friendly investment. The EKC findings (reported in Table 8) suggest that it would take several more years to achieve the threshold point for low-income groups than it would for developed and developing countries to do so, but again underdeveloped economies are likely to attract significant trade effects from advanced industrial countries over time. Low-income economies, however, produce less pollution compared to industrialized economies. Thus, in order to achieve global development goals, the various threshold points provide supports for individual economies to restructure their domestic ecological laws. Moreover, we can conclude that due to global economic costs, pollution in the atmosphere as a result of trade openness has an extremely negative influence on air quality. A similar reference was realized in the various income panels, but with different turning points. In addition, with regard to the negative externalities related to emissions in the atmosphere, achieving the threshold level is possible in the very short term through effective international treaties and policy tools. Even though developing countries are theoretically expected to decrease their trade volumes for lower greenhouse gasses, reducing trans-boundary greenhouse gasses as well as negative spillover impacts requires international environmental collaboration.

According to Beghin et al. [70], cooperation focused on technology distribution enhances environmental quality by promoting efficiency gains and modernization. The integration of environmental provisions into a trade agreement has therefore been identified by different countries as the most efficient means of protecting the world economy. Trade agreements should therefore reinforce the ability of governments to address concerns associated with the environment. Likewise, dropping trade barriers on environmentally friendly goods may increase green innovations at a minimum cost. For example, the Trans-Pacific Partnership (TPP) treaty was committed to helping emerging economies move into clean sectors and further adopts low-carbon mechanisms through the production of eco-friendly commodities and investments [71]. Efforts to reduce coal use must be accelerated by delaying new coal plants, actively promoting electrification in the industry and clean heating in buildings, efficiently pricing carbon, and providing coal-dependent countries with targeted support for renewable energy and economic transition. Our results show that more trade does not necessarily induce emissions, and the reverse is also true, as countries are gradually adopting eco-friendly production technologies. This transformation will reduce the heavy reliance on conventional energy for production 
and improve environmental quality in the long term. In general, reducing environmental pollution without negatively affecting trade volumes and real income calls on power-dependent countries to help develop generation capacity and renewable energy investment as well as restructure energy saving efforts to curb excessive energy lost. In addition, the current economic barriers to the promotion of renewable energy must be eliminated by working to improve coordination between authorities, providing adequate subsidies for developers, mitigating green investment risks, and gradually implementing renewable energy markets [72].

Even though the above analysis gives valuable insight into this topic, it should be acknowledged that developing efficient energy and trade agreements committed to reducing environmental pollution and maintaining real GDP growth must take into account macroeconomic determinants other than the ones used in our study. In addition, the study was performed using a dataset collected for individual countries: Hence, the average emissions and the cross-country variations in emissions levels were likely to be influenced by factors affecting global trade. In addition, several indicators for measuring emissions are available in the literature, such as $\mathrm{SO}_{2}, \mathrm{NO}$, etc.: All of this must be taken into consideration when selecting trade-related emissions data. Future expansions of this study should also take into account urbanization, sustainable energy distribution, sustainable development issues, innovation, human capital development, environmental regulation policy, etc., in multivariate analyses.

Author Contributions: This research was conceptualized by H.S. and S.A.C.; S.A.C. and H.S. formulated the methodology. Software, S.A.C. and J.C.K.A.; validation, H.S., K.F. and Y.G.; formal analysis, S.A.C.; writing-original draft preparation, H.S. and S.A.C.; writing—review and editing, S.A.C. and J.C.K.A.

Funding: We are also grateful for the financial support provided by the National Natural Science Foundation of China (No. 71774071, 71690241, 71810107001, 71834003, 71673230), the China Postdoctoral Science Foundation (No.2016M601568), the Strategic Priority Research Program of Chinese Academy of Sciences, Pan-Third Pole Environment Study for a Green Silk Road (Pan-TPE) (XDA20040400), the Soft Science Project in Zhenjiang (YJ2018004), and the Young Academic Leader Project of Jiangsu University (5521380003).

Acknowledgments: The authors cherished the precious remarks of the unknown referees.

Conflicts of Interest: The authors declare no conflicts of interest.

\section{References}

1. WTO. 2017. Available online: https://www.wto.org/english/news_e/news17_e/fac_31jan17_e.htm (accessed on 10 February 2019).

2. United Nations Statistics Division. 2017. Available online: https://comtrade.un.org/data (accessed on 10 February 2019).

3. Peters, G.P.; Minx, J.C.; Weber, C.L.; Edenhofer, O. Growth in emission transfers via international trade from 1990 to 2008. Proc. Natl. Acad. Sci. USA 2011, 108, 8903-8908. [CrossRef]

4. Antweiler, W.; Copeland, B.R.; Taylor, M.S. Is free trade good for the environment? Am. Econ. Rev. 2001, 91, 877-908. [CrossRef]

5. Cole, M.A.; Elliott, R.J.R. Determining the trade-Environment composition effect: The role of capital, labor and environmental regulations. J. Environ. Econ. Manag. 2003, 46, 363-383. [CrossRef]

6. Shahbaz, M.; Nasreen, S.; Ahmed, K.; Hammoudeh, S. Trade openness-Carbon emissions nexus: The importance of turning points of trade openness for country panels. Energy Econ. 2017, 61, $221-232$. [CrossRef]

7. Sebri, M.; Ben-Salha, O. On the causal dynamics between economic growth, renewable energy consumption, $\mathrm{CO}_{2}$ emissions and trade openness: Fresh evidence from BRICS countries. Renew. Sustain. Energy Rev. 2014, 39, 14-23. [CrossRef]

8. Andersson, F.N.G. International trade and carbon emissions: The role of Chinese institutional and policy reforms. J. Environ. Manag. 2018, 205, 29-39. [CrossRef]

9. Sbia, R.; Shahbaz, M.; Hamdi, H. A contribution of foreign direct investment, clean energy, trade openness, carbon emissions and economic growth to energy demand in UAE. Econ. Model. 2014, 36, 191-197. [CrossRef]

10. Boutabba, M.A. The impact of financial development, income, energy and trade on carbon emissions: Evidence from the Indian economy. Econ. Model. 2014, 40, 33-41. [CrossRef] 
11. Huang, Y. Understanding China's Belt \& Road Initiative: Motivation, framework and assessment. China Econ. Rev. 2016, 40, 314-321. [CrossRef]

12. Chang, Y.-C. The '21st Century Maritime Silk Road Initiative' and naval diplomacy in China. Ocean. Coast. Manag. 2018, 153, 148-156. [CrossRef]

13. Cullinane, K.P.B.; Lee, P.T.-W.; Yang, Z.; Hu, Z.-H. Editorial: China's Belt and Road Initiative. Transp. Res. Part E Logist. Transp. Rev. 2018, 117, 1-4. [CrossRef]

14. US EIA. 2009. Available online: https://www.eia.gov/beta/international/ (accessed on 12 February 2019).

15. Liu, Z.; Davis, S.J.; Feng, K.; Hubacek, K.; Liang, S.; Anadon, L.D.; Chen, B.; Liu, J.; Yan, J.; Guan, D. Targeted opportunities to address the climate-trade dilemma in China. Nat. Clim. Chang. 2016, 6, 201-206. [CrossRef]

16. Anderson, J.E.; Wulfhorst, G.; Lang, W. Energy analysis of the built environment-A review and outlook. Renew. Sustain. Energy Rev. 2015, 44, 149-158. [CrossRef]

17. Ren, S.; Yuan, B.; Ma, X.; Chen, X. The impact of international trade on China's industrial carbon emissions since its entry into WTO. Energy Policy 2014, 69, 624-634. [CrossRef]

18. Hasanov, F.J.; Liddle, B.; Mikayilov, J.I. The impact of international trade on $\mathrm{CO}_{2}$ emissions in oil exporting countries: Territory vs consumption emissions accounting. Energy Econ. 2018, 74, 343-350. [CrossRef]

19. Cherniwchan, J.; Copeland, B.R.; Taylor, M.S. Trade and the environment: New methods, measurements, and results. Annu. Rev. Econ. 2017, 9, 59-85. [CrossRef]

20. Liu, Y.; Hao, Y. The dynamic links between $\mathrm{CO}_{2}$ emissions, energy consumption and economic development in the countries along "the Belt and Road". Sci. Total Environ. 2018, 645, 674-683. [CrossRef]

21. Jiang, Y.; Sheu, J.-B.; Peng, Z.; Yu, B. Hinterland patterns of China Railway (CR) express in China under the Belt and Road Initiative: A preliminary analysis. Transp. Res. Part E Logist. Transp. Rev. 2018, 119, 189-201. [CrossRef]

22. Rauf, A.; Liu, X.; Amin, W.; Ozturk, I.; Rehman, O.U.; Sarwar, S. Energy and ecological sustainability: Challenges and panoramas in Belt and Road Initiative countries. Sustainability 2018, 10, 2743. [CrossRef]

23. Grossman, G.M.; Krueger A., B. Environmental Impacts of a North American Free Trade Agreement; The National Bureau of Economic Research: Cambridge, MA, USA, 1991; pp. 1-57. [CrossRef]

24. Shafik, N.; Bandyopadhyay, S. Economic Growth and Environmental Quality: Time-Series and Cross-Country Evidence. 1992. Available online: http://documents.worldbank.org/curated/en/833431468739515725/Economicgrowth-and-environmental-quality-time-series-and-cross-country-evidence (accessed on 10 February 2019).

25. Beckerman, W. 'Sustainable development': Is it a useful concept? Environ. Values 1994, 3, 191-209. [CrossRef]

26. Engle, R.F.; Granger, C.W.J. Co-integration and error correction: Representation, estimation, and testing. Econometrica 1987, 55, 251-276. [CrossRef]

27. Pedroni, P. Critical values for cointegration tests in heterogeneous panels with multiple regressors. Oxford Bull. Econ. Stat. 1999, 61, 653-670. [CrossRef]

28. Copeland, B.R.; Taylor, M.S. Trade, growth, and the environment. J. Econ. Lit. 2004, 42, 7-71. [CrossRef]

29. Farhani, S.; Chaibi, A.; Rault, C. $\mathrm{CO}_{2}$ emissions, output, energy consumption, and trade in Tunisia. Econ. Model. 2014, 38, 426-434. [CrossRef]

30. Copeland, B.R.; Taylor, M.S. Trade and the Environment: Theory and Evidence; Princeton University Press: Princeton, NJ, USA, 2003.

31. Grossman, G.M.; Krueger, A.B. Economic growth and the environment. Q. J. Econ. 1995, 110, $353-377$. [CrossRef]

32. Power, A.L.; Tennant, R.K.; Jones, R.T.; Tang, Y.; Du, J.; Worsley, A.T.; Love, J. Monitoring impacts of urbanisation and industrialisation on air quality in the Anthropocene using urban pond sediments. Front. Earth Sci. 2018, 6, 1-18. [CrossRef]

33. Omri, A. $\mathrm{CO}_{2}$ emissions, energy consumption and economic growth nexus in MENA countries: Evidence from simultaneous equations models. Energy Econ. 2013, 40, 657-664. [CrossRef]

34. Shahbaz, M.; Hye, Q.M.A.; Tiwari, A.K.; Leitão, N.C. Economic growth, energy consumption, financial development, international trade and $\mathrm{CO}_{2}$ emissions in Indonesia. Renew. Sustain. Energy Rev. 2013, 25, 109-121. [CrossRef]

35. Sohag, K.; Al Mamun, M.; Uddin, G.S.; Ahmed, A.M. Sectoral output, energy use, and $\mathrm{CO}_{2}$ emission in middle-income countries. Environ. Sci. Pollut. Res. 2017, 24, 9754-9764. [CrossRef]

36. Managi, S.; Hibiki, A.; Tsurumi, T. Does trade openness improve environmental quality? J. Environ. Econ. Manag. 2009, 58, 346-363. [CrossRef] 
37. Jayanthakumaran, K.; Verma, R.; Liu, Y. $\mathrm{CO}_{2}$ emissions, energy consumption, trade and income: A comparative analysis of China and India. Energy Policy 2012, 42, 450-460. [CrossRef]

38. Arouri, M.E.H.; Ben Youssef, A.; M'Henni, H.; Rault, C. Energy consumption, economic growth and $\mathrm{CO}_{2}$ emissions in Middle East and North African countries. Energy Policy 2012, 45, 342-349. [CrossRef]

39. Salahuddin, M.; Alam, K.; Ozturk, I.; Sohag, K. The effects of electricity consumption, economic growth, financial development and foreign direct investment on $\mathrm{CO}_{2}$ emissions in Kuwait. Renew. Sustain. Energy Rev. 2018, 81, 2002-2010. [CrossRef]

40. Farhani, S.; Ozturk, I. Causal relationship between $\mathrm{CO}_{2}$ emissions, real GDP, energy consumption, financial development, trade openness, and urbanization in Tunisia. Environ. Sci. Pollut. Res. 2015, 22, 15663-15676. [CrossRef]

41. Keppler, J.H.; Mansanet-Bataller, M. Causalities between $\mathrm{CO}_{2}$, electricity, and other energy variables during phase I and phase II of the EU ETS. Energy Policy 2010, 38, 3329-3341. [CrossRef]

42. Pao, H.-T.; Tsai, C.-M. $\mathrm{CO}_{2}$ emissions, energy consumption and economic growth in BRIC countries. Energy Policy 2010, 38, 7850-7860. [CrossRef]

43. Ghosh, S. Examining carbon emissions economic growth nexus for India: A multivariate cointegration approach. Energy Policy 2010, 38, 3008-3014. [CrossRef]

44. Zhang, X.-P.; Cheng, X.-M. Energy consumption, carbon emissions, and economic growth in China. Ecol. Econ. 2009, 68, 2706-2712. [CrossRef]

45. Selden, T.M.; Song, D. Environmental quality and development: Is there a Kuznets curve for air pollution emissions? J. Environ. Econ. Manag. 1994, 27, 147-162. [CrossRef]

46. Saboori, B.; Sulaiman, J.; Mohd, S. Economic growth and $\mathrm{CO}_{2}$ emissions in Malaysia: A cointegration analysis of the environmental Kuznets curve. Energy Policy 2012, 51, 184-191. [CrossRef]

47. Ozturk, I.; Acaravci, A. $\mathrm{CO}_{2}$ emissions, energy consumption and economic growth in Turkey. Renew. Sustain. Energy Rev. 2010, 14, 3220-3225. [CrossRef]

48. Fodha, M.; Zaghdoud, O. Economic growth and pollutant emissions in Tunisia: An empirical analysis of the environmental Kuznets curve. Energy Policy 2010, 38, 1150-1156. [CrossRef]

49. Acheampong, A.O. Economic growth, $\mathrm{CO}_{2}$ emissions and energy consumption: What causes what and where? Energy Econ. 2018, 74, 677-692. [CrossRef]

50. Gorus, M.S.; Aydin, M. The relationship between energy consumption, economic growth, and $\mathrm{CO}_{2}$ emission in MENA countries: Causality analysis in the frequency domain. Energy 2019, 168, 815-822. [CrossRef]

51. Boulatoff, C.; Jenkins, M. Long-term nexus between openness, income, and environmental quality. Int. Adv. Econ. Res. 2010, 16, 410-418. [CrossRef]

52. Dogan, E.; Turkekul, B. $\mathrm{CO}_{2}$ emissions, real output, energy consumption, trade, urbanization and financial development: testing the EKC hypothesis for the USA. Environ. Sci. Pollut. Res. 2016, 23, 1203-1213. [CrossRef]

53. Kasman, A.; Duman, Y.S. $\mathrm{CO}_{2}$ emissions, economic growth, energy consumption, trade and urbanization in new EU member and candidate countries: A panel data analysis. Econ. Model. 2015, 44, 97-103. [CrossRef]

54. Al-Mulali, U.; Ozturk, I. The effect of energy consumption, urbanization, trade openness, industrial output, and the political stability on the environmental degradation in the MENA region. Energy 2015, 84, 382-389. [CrossRef]

55. Farhani, S.; Mrizak, S.; Chaibi, A.; Rault, C. The environmental Kuznets curve and sustainability: A panel data analysis. Energy Policy 2014, 71, 189-198. [CrossRef]

56. Kohler, $\mathrm{M} . \mathrm{CO}_{2}$ emissions, energy consumption, income and foreign trade: A South African perspective. Energy Policy 2013, 63, 1042-1050. [CrossRef]

57. Stern, D.I. The environmental Kuznets curve after 25 years. J. Bioecon. 2017, 19, 7-28. [CrossRef]

58. Pesaran, M.H. General Diagnostic Tests for Cross Section Dependence in Panels. 2004, pp. 1-41. Available online: https://ssrn.com/abstract=572504 (accessed on 10 February 2019).

59. Pesaran, M.H.; Ullah, A.; Yamagata, T. A bias-adjusted LM test of error cross-section independence. Econ. J. 2008, 11, 105-127. [CrossRef]

60. Breusch, T.S.; Pagan, A.R. The lagrange multiplier test and its applications to model specification in econometrics. Rev. Econ. Stud. 1980, 47, 239-253. [CrossRef]

61. Levin, A.; Lin, C.-F.; James Chu, C.-S. Unit root tests in panel data: Asymptotic and finite-sample properties. J. Econ. 2002, 108, 1-24. [CrossRef] 
62. Im, K.S.; Pesaran, M.H.; Shin, Y. Testing for unit roots in heterogeneous panels. J. Econ. 2003, 115, 53-74. [CrossRef]

63. Sinha, A.; Bhattacharya, J. Estimation of environmental Kuznets curve for $\mathrm{SO}_{2}$ emission: A case of Indian cities. Ecol. Indic. 2017, 72, 881-894. [CrossRef]

64. Baltagi, B.H.; Demetriades, P.O.; Law, S.H. Financial development and openness: Evidence from panel data. J. Dev. Econ. 2009, 89, 285-296. [CrossRef]

65. Bildirici, M.E.; Kayıkçı, F. Economic growth and electricity consumption in former Soviet Republics. Energy Econ. 2012, 34, 747-753. [CrossRef]

66. Pedroni, P. Fully modified OLS for heterogeneous cointegrated panels. In Nonstationary Panels, Panel Cointegration, and Dynamic Panels (Advances in Econometrics, Volume 15); Emerald Group Publishing Limited: Bingley, UK, 2001; pp. 93-130. [CrossRef]

67. Frankel, J.; Rose, A. Is trade good or bad for the environment? Sorting out the causality. Rev. Econ. Stat. 2005, 87, 85-91. [CrossRef]

68. Ozturk, I.; Uddin, G.S. Causality among carbon emissions, energy consumption and growth in India. Econ. Res. Ekonomska Istraživanja 2012, 25, 752-775. [CrossRef]

69. Mardani, A.; Streimikiene, D.; Cavallaro, F.; Loganathan, N.; Khoshnoudi, M. Carbon dioxide $\left(\mathrm{CO}_{2}\right)$ emissions and economic growth: A systematic review of two decades of research from 1995 to 2017. Sci. Total Environ. 2019, 649, 31-49. [CrossRef]

70. Beghin, J.; Roland-Holst, D.; Van der Mensbrugghe, D. Trade liberalization and the environment in the Pacific Basin: Coordinated approaches to Mexican trade and environment policy. Am. J. Agric. Econ. 1995, 77, 778-785. [CrossRef]

71. Meltzer, J.P. Trade Liberalization and International Co-Operation: A Legal Analysis of the Trans-Pacific Partnership Agreement, Edward Elgar. 2014, pp. 1-32. Available online: https://ssrn.com/abstract=2326723 (accessed on 15 February 2019).

72. Outlook, C.s.R.E. 2018. Available online: http://www.cnrec.org.cn/English/ (accessed on 15 February 2019).

(C) 2019 by the authors. Licensee MDPI, Basel, Switzerland. This article is an open access article distributed under the terms and conditions of the Creative Commons Attribution (CC BY) license (http://creativecommons.org/licenses/by/4.0/). 